\title{
Rich Family, Poor Family: Investment Portfolios And Case Studies From "USA Today"
}

Ronald L. Moy, St. John's University, USA

Ralph Terregrossa, St. John's University, USA

\begin{abstract}
Case studies have become an integral part of the business education curriculum. However, opportunities to use this approach in financial planning are limited because of the lack of cases about individual investors. Although parents could share their finances with their children, a brief survey we conducted indicates that our students are not getting the opportunity to examine the personal financial information of their family members or friends either. This void is leaving students unprepared to enter into careers in financial planning and brokerage. This paper discusses the use of a long-running monthly column from USA Today entitled "Your Portfolio," which provides cases on individual investing. The articles can be used to provide students with the opportunity to view the real-world financial circumstances of a range of individuals and to analyze and recommend the best course of action.
\end{abstract}

Keywords: investment policy, financial planning, asset allocation

\section{INTRODUCTION}

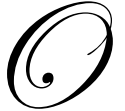

ne of the keys to mastering a topic is to gain hands on experience. It's hard to imagine Tiger Woods, Pablo Picasso or renowned orthopedic surgeon, Dr. James Andrews, rising to the top of their professions by simply reading about their respective fields. Yet in the case of investing, students, who will pursue careers as brokers or financial planners, leave school with little hands-on experience in the management of an individual's investment portfolio.

The use of case studies is not new to the field of finance. In corporate finance courses, it is easy to conduct hands-on analysis through the numerous case studies that have been written about actual and fictitious companies. In addition, the advent of the Internet has made it easy for students to obtain actual financial information about a corporation from the company's web site, through the SEC's Edgar web site or through third parties such as Yahoo.

Unlike the financial information for corporations, information on an individual's personal finances can be difficult to obtain. With the exception of candidates for political office, individuals do not make their personal finances available for public scrutiny. This makes it difficult for students to have the opportunity to analyze actual personal financial data for a diverse sample of individuals. Even though investment and portfolio management texts could incorporate some personal financial cases, most stick to the traditional topics of valuation, fundamental analysis and asset pricing, choosing to pay little attention to actual personal investment portfolios.

This article offers suggestions for providing students with an opportunity to examine the financial position of individuals with varying investment circumstances, to review the portfolio allocations, to analyze the risk of the investor's portfolio, and to offer recommendations on how the individual can improve his or her portfolio. 


\section{THE IMPORTANCE OF PRACTICAL ASSET ALLOCATION}

Movement away from the traditional defined benefit pension plan to defined contribution plans has made it more critical for individuals to understand the steps to producing a sound investment portfolio and has increased the importance of the financial planning profession. The Employee Benefit Research Institute reports that in 1979, the sole retirement plan for 62 percent of workers was a defined benefit plan, however by 2005, 63 percent of employees found themselves covered only by voluntary defined contribution plans. This change in retirement plans, the business scandals involving Enron, World Com and Tyco, the collapse of many dot com companies and the financial crisis of 2008 indicates the importance that must be placed on personal investment strategies. Although much of the financial devastation that shareholders suffered could be attributed to unwise or fraudulent practices, many investors magnified their financial losses by implementing imprudent investment strategies. Many of these investors could have mitigated their financial losses due to these unforeseen events had they engaged in prudent investment practices, which begins with a review of their financial objectives and constraints an individual faces, and a sound asset allocation strategy.

\section{AN OVERVIEW OF THE INVESTMENT POLICY STATEMENT}

One of the most important and overlooked principles of investments is the construction of an investment policy statement. Although most investment textbooks do an adequate job of teaching such traditional topics as financial statement analysis, valuation and market efficiency, only a handful of texts cover investment policy [Reilly and Norton,1999] or [Strong, 2006]. The topic of investment policy is considered so important to the CFA Institute that numerous readings on this subject are included in their Chartered Financial Analyst program.

Essentially, the investment policy statement helps to assist the money manager by providing the objectives and constraints that the investor faces in constructing his/her investment portfolio. These objectives and constraints allow the money manager to tailor the portfolio to the individuals' specific needs. The investment policy statement also serves as a contract between the money manager and the client and protects both by laying out the investment action to be taken.

The objectives of an investor are the starting point for preparing a sound financial plan. The objectives need to clearly outline realistic goals for the investor. Objectives such as making as much money as possible are too broad to allow a money manager or the investor to produce a sound financial plan. In fact, broad objectives like this may actually lead a money manager to invest the client's funds inappropriately. The objectives consist of the return and risk preferences of the investor. For example, the goal of a recent college graduate to become a millionaire by age 30 may be unrealistic, given this person's $\$ 50,000$ per year job. However, the goal of saving a sufficient amount of money to be able to retire at age 55 may be attainable with a sound financial plan.

In addition to the objectives, each investor will face a number of constraints that will help determine the appropriate assets to be included in his or her portfolio. Constraints that the investor will face include his time horizon, liquidity needs, tax circumstances, and any unique preferences or circumstances.

\section{AN OVERVIEW OF ASSET ALLOCATION}

Many financial experts consider the asset allocation decision to be the most critical decision an investor will face. Although many individuals consider the ability to identify the next Microsoft, Starbucks or Google the key to investment success, asset allocation plays a much more important role in the performance of an investment portfolio. In a now classic article in the Financial Analysts Journal, [Brinson, Hood and Beebower, 1986] showed that 93.6 percent of the total plan return could be explained by the plan's asset allocation.

Asset allocation draws on the tools of portfolio theory and shows how investors should combine different financial assets to form the best possible portfolio to achieve their objectives. However, unlike modern portfolio theory, where there are numerous restrictive assumptions, such as homogeneous expectations, no transaction costs and no taxes, which leads to an optimal portfolio, there may be many "best" portfolios consistent with the investor's circumstances. The longer an investor's time horizon and the greater the investor's tolerance for risk, the more the 
portfolio can be tilted toward higher risk, higher return assets. Many investors mistakenly assume that the converseinvestors with shorter time horizons and lower tolerances for risk should hold only low risk assets-is also true. There are two reasons why individuals with low tolerances for risk can, and arguably, should hold some high risk assets. First, low return assets increase the risk that the individual will lose purchasing power through increases in the price level. Second, portfolio theory tells us that it may be possible to combine high-risk assets in a portfolio and increase the return of the portfolio while actually reducing the total risk of the portfolio.

\section{STUDENT EXPERIENCE WITH PERSONAL FINANCIAL DATA}

One of the difficulties with conducting case studies of personal investing is obtaining personal financial data. [Peavy and Sherrard, 1990] provide some personal financial cases in a book that consists of past exams from the Chartered Financial Analyst program. Each case contains information about the individual or institution and tips and answers for constructing an investment policy statement and an asset allocation. Although the book is instructive and informative, it contains many cases that are "spiced up" and many students may find the cases unrealistic. In addition, the book devotes only three cases to individual investors while devoting eight cases to institutional investing.

In order to determine if the current generation of students is privy to actual personal financial information, we conducted a brief survey of students in two Introduction to Business classes (51 students responded). We were interested in finding out if the once taboo subject of personal finances were now being discussed both inside and outside of the home.

In our survey we found some interesting results. We were surprised to find that 76.47 percent of students reported that they had discussed personal finance with their parents. However, upon further analysis, the topics for discussion were predominately limited to salary and benefits, size of mortgage and college savings $(62.74 \%, 49.02 \%$ and $47.06 \%$ respectively). Topics such as retirement and non-retirement savings were discussed far less frequently $(23.53 \%$ and $13.73 \%)$. In addition, 51 percent of students reported that the discussions were general in nature and did not include any specific information.

We were also curious if students had discussed personal finance with other friends or family members. Here the numbers are more consistent with what we would expect apriori. More than 64 percent of students responded that they did not discuss personal financial matters with others. In addition, students were unanimous in their feelings that seeing other people's finances and getting the advice from a financial planner would be beneficial. Table 1 presents the results from our survey.

Although instructors can ask students to obtain financial information from their parents or other family members, there are a couple of problems with this approach. First, as our survey seems to indicate, many parents may be uncomfortable divulging such personal information to their children, especially if the information is likely to be viewed by others. Second, even if most parents are willing to provide such information, there will be little diversity in the age and earnings cycle for the parents. Most parents of college age students will range in age from their early forties to their mid fifties and will be in the same phase of their investment life cycle. Investment allocations for most of the participants will be similar, thus limiting the opportunity for students to see how age influences the allocation decision.

\section{USA TODAY'S "YOUR PORTFOLIO" COLUMN}

An ample source of actual cases regarding individual investors is the monthly column in USA Today entitled "Your Portfolio." The column, which usually appears the first Monday of the month in the "Money" section of the paper (issues dating back less than 30 days can be found for free by searching the USA Today website www.usatoday.com, past issues are available from Pro Quest, which is available at many colleges.) The column consists of personal financial information, which readers are invited to submit for review by a professional financial planner. In addition to the financial information, the participants also provide some information on their objectives, such as when they would like to retire and how they may be spending their money in the future. 


\begin{tabular}{|c|c|c|}
\hline nal Finance Survey & $\mathbf{N}$ & Percent \\
\hline \multicolumn{3}{|l|}{ 1. Have your parents ever discussed their personal finances with you? } \\
\hline Yes & 39 & $76.47 \%$ \\
\hline No & 12 & $23.52 \%$ \\
\hline \multicolumn{3}{|l|}{ 2. If you answered yes to Question (1), which of the following have they discussed with you. (Check all that apply). } \\
\hline Their salary and benefits. & 32 & $62.74 \%$ \\
\hline Their retirement savings. & 12 & $23.53 \%$ \\
\hline Their non-retirement savings. & 7 & $13.73 \%$ \\
\hline The size of their mortgage. & 25 & $49.02 \%$ \\
\hline Their credit card debt. & 17 & $33.33 \%$ \\
\hline Their life insurance. & 12 & $23.53 \%$ \\
\hline Other debt. & 11 & $21.57 \%$ \\
\hline Any real estate investments. & 10 & $19.61 \%$ \\
\hline College savings for you or your siblings & 24 & $47.06 \%$ \\
\hline Other (please specify) & 5 & $9.80 \%$ \\
\hline \multicolumn{3}{|l|}{ 3. If you checked any of the financial information in question (2), how specific was the information you were given } \\
\hline General information about the money but not the details on the amounts. & 26 & $50.98 \%$ \\
\hline Specific information on both the accounts and the dollar amounts in the accounts. & 11 & $21.57 \%$ \\
\hline Have you actually seen the documents relating to the financial information (ex. Brokerage or mutual fund statement). & 4 & $7.84 \%$ \\
\hline \multicolumn{3}{|l|}{ 4. Have your parents ever explained to you how they manage their finances? } \\
\hline Yes & 20 & $39.22 \%$ \\
\hline No & 19 & $37.25 \%$ \\
\hline \multicolumn{3}{|l|}{ 5. To the best of your knowledge do your parents use a financial planner, broker or insurance agent. } \\
\hline Yes & 13 & $25.49 \%$ \\
\hline No & 27 & $52.94 \%$ \\
\hline \multicolumn{3}{|l|}{ 6. If you answered yes to question (5), have you ever met or spoken with them? } \\
\hline Yes & 4 & $7.84 \%$ \\
\hline No & 9 & $17.65 \%$ \\
\hline \multicolumn{3}{|l|}{$\begin{array}{l}\text { 7. Excluding sharing information on job offers with friends or family, has anyone other than your parents } \\
\text { shared personal financial information with you? }\end{array}$} \\
\hline Yes & 18 & $35.29 \%$ \\
\hline No & 33 & $64.71 \%$ \\
\hline \multicolumn{3}{|l|}{ 8. If you answered yes to question (7), please check all individuals that shared information } \\
\hline Sibling & 8 & $15.69 \%$ \\
\hline Grandparent & 5 & $9.80 \%$ \\
\hline Uncle/aunt & 9 & $17.65 \%$ \\
\hline Friend & 11 & $21.57 \%$ \\
\hline
\end{tabular}


Table 1, Continued

Percent

9. If you answered yes to question (8), which of the following have they discussed with you (check all that apply).

Their salary and benefits.

Their retirement savings.

Their non-retirement savings.

The size of their mortgage.

Their credit card debt.

Their life insurance.

Other debt.

Any real estate investments.

Other

10. If you checked any of the information in question (9), how specific was the information you were given.

General information about the money but not the details on the amounts.

Specific information on both the accounts and the dollar amounts in the accounts.

Have you actually seen the documents relating to the financial information (ex. Brokerage or mutual fund statement).

11. Do you think you could benefit from seeing how other people manage their finances?

Yes

No

15

\section{$29.41 \%$}

$5.88 \%$

$1.96 \%$

$7.84 \%$

$11.76 \%$

$1.96 \%$

$7.84 \%$

$11.76 \%$

$0.00 \%$

12. Do you think you could benefit from seeing how a professional financial planner would help individuals manage their finances?

Yes

No

$12 \quad 23.53 \%$

$6 \quad 11.76 \%$

$0.00 \%$

$49 \quad 100.00 \%$

$0 \quad 0.00 \%$

13. What is your gender?

Female

Male

$51 \quad 100.00 \%$

$0.00 \%$

14. Do you have any siblings?

Yes

15. Did your parents go to college?

Yes, both graduated from college.

One graduated from college, but the other did not attend.

No, neither attended college.

Both attended college, but neither graduated.

Both attended college, but only one graduated.

One attended, but didn't graduate.

$\begin{array}{ll}11 & 21.57 \% \\ 12 & 23.53 \% \\ 20 & 39.22 \% \\ 2 & 3.92 \% \\ 4 & 7.84 \% \\ 2 & 3.92 \%\end{array}$


Table 2

Selected "Your Portfolio" Column

\begin{tabular}{|c|c|c|c|c|c|}
\hline \multicolumn{6}{|c|}{ Selected "Your Portfolio" Columns } \\
\hline Date & Individual(s) & Age & Income/Employment & Savings & Issue \\
\hline $6 / 3 / 00$ & Mr. J.M. Krummel & 38 & $<\$ 30 \mathrm{k}$, actor & $\$ 32 \mathrm{k}$ & Retirement \\
\hline $7 / 3 / 00$ & Mr. J. Martin & 41 & & $\$ 265 \mathrm{k}$ & Early retirement. 2 children $(5 \& 8)$ college. \\
\hline $12 / 4 / 00$ & Mr. M. Duguay & 43 & $\$ 100 \mathrm{k}$ GM restaurant & $\$ 183 \mathrm{k}$ & 2 children ( $13 \& 11)$ college. Retirement at 52 \\
\hline $1 / 2 / 01$ & Mr. C. Reed & 43 & $\$ 100 \mathrm{k}$ salesman & $\$ 530 \mathrm{k}$ & \\
\hline $2 / 5 / 01$ & M/M K. Johnson & $36 / 35$ & $\$ 65-85 \mathrm{k}$ performer & $\$ 166 \mathrm{k}$ & Reduce schedule by 56 , retire at 60 or 65 . \\
\hline $3 / 5 / 01$ & Ms. J. Jacobson & 26 & $\$ 5 \mathrm{k}$ teaching asst/student & $\$ 12 \mathrm{k}$ & Financial security/retirement \\
\hline $5 / 7 / 01$ & Mr. S. Lewis & 29 & $\$ 100 \mathrm{k}$ sales/real estate & $\$ 675 \mathrm{k}$ & Managing savings \\
\hline $6 / 4 / 01$ & M/M R. Johnson & $35 / 34$ & $\$ 60 \mathrm{k}$ gov employee & $\$ 175 \mathrm{k}$ & $\begin{array}{l}\text { Retirement at } 55.2 \text { children ( } 2 \text { and } 6 \text { months) } \\
\text { college. }\end{array}$ \\
\hline $7 / 2 / 01$ & Mr. M. Hoffman & 55 & $\$ 300 \mathrm{k}$ public relations & $\$ 688 \mathrm{k}$ & Begin reducing work schedule. \\
\hline $8 / 6 / 01$ & M/M J. Meaders & $52 / 49$ & $\$ 75 \mathrm{k}$ university employees & $\$ 195 \mathrm{k}$ & Maintaining standard of living during retirement. \\
\hline $9 / 4 / 01$ & Mr. A Throckmorton & 41 & $\$ 90 \mathrm{k}-\$ 120 \mathrm{k}$ car sales & $\$ 136 \mathrm{k}$ & Retirement. \\
\hline $10 / 1 / 01$ & M/M J. Rannochio & $66 / 62$ & $\$ 100 \mathrm{k}$ pension, SS part time work & $\$ 418 \mathrm{k}$ & Retirement \\
\hline $12 / 3 / 01$ & M/M. G. Nichols & $34 / 34$ & $\$ 109 \mathrm{k}$ computer/bank man & $\$ 229 \mathrm{k}$ & $\begin{array}{l}\text { Save for } 21 / 2 \text { month olds college. } 529 \text { plan } \\
\text { Retirement around } 60 .\end{array}$ \\
\hline $5 / 6 / 02$ & Mr. W. Young & 28 & $\$ 50 \mathrm{k}$ cpt. airforce & $\$ 35 \mathrm{k}$ & Retirement. Money management fees \\
\hline $6 / 3 / 02$ & M/M M. Mortland & $40 / 40$ & $\$ 165 \mathrm{k}$ mort broker/admin asst. & $\$ 302 \mathrm{k}$ & 2 children $(11 \& 10)$ college. Retirement \\
\hline $8 / 5 / 02$ & Mr. D. Spinogatti & 29 & $\$ 150 k$ comp v.p. & $\$ 200 \mathrm{k}$ & $\begin{array}{l}\text { House purchase in next couple of years. Buy a } \\
\text { health club business. }\end{array}$ \\
\hline $9 / 3 / 02$ & M/M. D. DeMarco & 40 & $\$ 140 \mathrm{k}$ contractor/fashion wholesaler & $\$ 222 \mathrm{k}$ & Retirement. \\
\hline $10 / 7 / 02$ & M/M. R. Moore & & $\begin{array}{l}\$ 147 \mathrm{k} \text { from dividends \& interest/ } \\
\text { retired }\end{array}$ & $\$ 1.1$ million & Money for their children. \\
\hline $1 / 6 / 03$ & Ms. S. Evans & 57 & $\$ 55 \mathrm{k}$ nurse & $\$ 298 \mathrm{k}$ & \\
\hline $2 / 3 / 03$ & Ms. M. King & 40 & $\$ 60 \mathrm{k}$ professional organizer & $\$ 87 \mathrm{k}$ & House purchase, retirement \\
\hline $3 / 3 / 03$ & M/M. G. Cardenas & & $\begin{array}{l}\text { Information consultant/Database } \\
\text { administrator }\end{array}$ & $\$ 330 \mathrm{k}$ & 3 children college funding \\
\hline $4 / 7 / 03$ & Mr. Kevin Smith & 52 & Retired & $\begin{array}{l}\text { \$660k winnings } \\
\text { from t.v. show }\end{array}$ & Supporting mother and sisters \\
\hline $5 / 5 / 03$ & M/M. Coppock & $50 / 50$ & $\$ 84 \mathrm{k}$ Fund raiser/administrative asst. & $\$ 60 \mathrm{k}$ & Son's college education and retirement \\
\hline $6 / 1 / 03$ & Ms. J. Stowers & 53 & \$66k Housing inspector & $\$ 56 \mathrm{k}$ & Retirement at 65 , leave some to daughters \\
\hline $8 / 3 / 03$ & M/M M. Hiller & $38 / 35$ & $\begin{array}{l}\$ 83 \mathrm{k} \text { Auto licensing } \\
\text { clerk/technical writer }\end{array}$ & $\$ 131 \mathrm{k}$ & Retire to home on lake while still young. \\
\hline $9 / 2 / 03$ & Mr. T. Ottinger & 39 & $\begin{array}{l}\text { \$75k including bonus Account } \\
\text { executive }\end{array}$ & $\$ 110 \mathrm{k}$ & Retire at 55 \\
\hline $11 / 3 / 03$ & M/M C. Dyer & $36 / 35$ & $\begin{array}{l}\$ 140 \mathrm{k} \text { plus bonuses Sales } \\
\text { manager/territory manager }\end{array}$ & $\$ 117 \mathrm{k}$ & New baby, retirement starting at 50 \\
\hline $12 / 1 / 03$ & Mr. D. Hannaman & 57 & Performance manager for U.S. Mint & $\begin{array}{l}\$ 463 \mathrm{k}+\text { house he } \\
\text { expects to clear } \\
\$ 400 \mathrm{k} \text { after } \\
\text { mortgage }\end{array}$ & Retirement \\
\hline
\end{tabular}




\begin{tabular}{|c|c|c|c|c|c|}
\hline Date & Individual(s) & Age & Income/Employment & Savings & Issue \\
\hline $2 / 2 / 04$ & M/M Litwiller & $28 / 27$ & $\begin{array}{l}\text { \$56k Operations manager/senior } \\
\text { biller }\end{array}$ & $\$ 172 \mathrm{k}$ & Have a family, can they live on one salary? \\
\hline $3 / 1 / 04$ & M/M Bobo & 48 & Collections officer/volleyball coach & $\$ 240 \mathrm{k}$ & $\begin{array}{l}\text { Retire in } 14 \text { years. Start wine business in } \\
\text { retirement. }\end{array}$ \\
\hline $5 / 3 / 04$ & Mr. R. Pyle & 52 & Retired & $\$ 700 \mathrm{k}$ & Retirement \\
\hline $7 / 6 / 04$ & Mr. M. Namy & 91 & Retired & $\$ 193 k$ & Beating the market \\
\hline $8 / 2 / 04$ & M/M T. Shaeffer & $35 / 33$ & $\begin{array}{l}\$ 89 \mathrm{k} \text { Sergeants in the National } \\
\text { Guard }\end{array}$ & $\begin{array}{l}\$ 20 \mathrm{k} \text { in credit card } \\
\text { debt }\end{array}$ & College for children, retirement at 50 or 55 \\
\hline $9 / 7 / 04$ & Ms. B. Theros & 44 & $\begin{array}{l}\$ 41 \mathrm{k} \text { Office manager + child } \\
\text { support }\end{array}$ & $\$ 109 k$ & Financial plan \\
\hline $11 / 1 / 04$ & M/M T. Casperson & $59 / 57$ & $\begin{array}{l}\$ 60-70 \mathrm{k} \text { Part-time tour guide/part- } \\
\text { time clerk }\end{array}$ & $\$ 856 \mathrm{k}$ & Managing portfolio \\
\hline $2 / 7 / 05$ & M/M/ G. Shayman & $32 / 34$ & Pilot & $\$ 200 \mathrm{k}$ & Retirement at 60 , funding children's education \\
\hline $3 / 7 / 05$ & Mr. S. Doud & 46 & Information technology director & $\$ 265 \mathrm{k}$ & Retire at 65 \\
\hline $4 / 4 / 05$ & Ms. K. Hehe & 46 & $\$ 50 \mathrm{k}$ auditor & $\$ 111 \mathrm{k}$ & Retirement \\
\hline $5 / 2 / 05$ & M/M R. McClarren & $44 / 30$ & $\$ 83 \mathrm{k}$ Training consultant & $\$ 264 \mathrm{k}$ & Retirement, saving for children's education \\
\hline $6 / 6 / 05$ & Mr. J. Cupo & 31 & Science and operations officer & $\$ 225 \mathrm{k}$ & Retire at 55 \\
\hline $8 / 1 / 05$ & Mr. K. Deshmukh & 24 & $\$ 18 \mathrm{k}$ Graduate student & $\$ 17 \mathrm{k}$ & House purchase in 4 years \\
\hline $11 / 7 / 05$ & M/M M. Hetmer & 41 & \$120k Mortgage broker/real estate & $\begin{array}{l}\text { \$200k credit card } \\
\text { and student loan } \\
\text { debt }\end{array}$ & Get out of debt \\
\hline $12 / 5 / 05$ & M/M R. Morris & 35 & $\begin{array}{l}\text { \$140k Managing auto body } \\
\text { shop/insurance company }\end{array}$ & $\begin{array}{l}\text { Net worth } \$ 850 \mathrm{k} \\
\$ 566 \mathrm{k} \text { in real } \\
\text { estate equity }\end{array}$ & Reducing risk \\
\hline $3 / 6 / 06$ & M/M B. Khoury & $61 / 63$ & Retired & $\$ 1.8$ million & Travel during retirement \\
\hline $8 / 7 / 06$ & $\begin{array}{l}\text { C. Yoes \& L. } \\
\text { Kukendall }\end{array}$ & $38 / 40$ & \$130k Programmer-analyst/attorney & $\$ 25 \mathrm{k}$ & Organizing and prioritizing finances \\
\hline $9 / 5 / 06$ & M/M S. Mills & $25 / 25$ & \$30k Law student/school teacher & $\$ 20 \mathrm{k}$ & Paying student loans and saving for future \\
\hline 10/2/06 & Ms. R. Crowe & 47 & $\begin{array}{l}\text { Former softball coach, trophy } \\
\text { business owner }\end{array}$ & $\$ 244 \mathrm{k}$ & Retire in 15 or 20 years \\
\hline $11 / 6 / 06$ & M/M D. Ebert & $56 / 50$ & $\begin{array}{l}\text { Retired from U.S. Forest Service, } \\
\text { environmental consultant/medical } \\
\text { technologist }\end{array}$ & $\$ 350 \mathrm{k}$ & Buying an organic farm \\
\hline $3 / 5 / 07$ & M/M Lai & $33 / 32$ & \$151k Therapist/physician & $\$ 62 \mathrm{k}$ & Retirement and financing children's education \\
\hline $8 / 6 / 07$ & M/M Williams & $46 / 40$ & $\begin{array}{l}\$ 153 \mathrm{k} \text { Manager for Defense } \\
\text { Logistics Agency/major in Army } \\
\text { reserve }\end{array}$ & $\$ 215 \mathrm{k}$ & Retirement \\
\hline 10/1/07 & Ms. L. Kempel & 48 & Flight attendant & $\$ 293 k$ & Home purchase/retirement \\
\hline $11 / 5 / 07$ & Mr. R. Crook & 63 & Retired & $\$ 652 \mathrm{k}$ & Retirement \\
\hline
\end{tabular}


The cases are excellent resources for teaching students because of the wide diversity of individuals who are featured in the column. Table 2 lists some of the past participants of the "Your Portfolio" column. The column has covered a wide range of individuals and couples of different ages, income levels and varying degrees of wealth. Some participants are saving for their children's college education, whereas others are nearing retirement. For example, past columns have reviewed the finances of Jens Martin Krummel, 38, a stage actor whose income doesn't usually exceed $\$ 30,000$ and who has savings of $\$ 35,000$ (June 5, 2000); Sherman Lewis, 29, a computer salesman and real estate investor with income of $\$ 100,000$ and $\$ 675,000$ in securities and equity in his real estate holdings (May 7, 2001); the Moore's, a married couple with $\$ 147,000$ in retirement income from interest and dividends and $\$ 1.1$ million in savings (October 7, 2002); and Mitchell Namy, 91, a retiree with $\$ 191,000$ in savings and penchant for taking investment risks ( July 6, 2004).

\section{USING THE CASES IN THE CLASSROOM}

The cases presented in the "Your Portfolio" column provide instructors with a number of opportunities for incorporating financial planning into the classroom. A simple use of the articles is to have students read the article and to use the information provided by the participants to stimulate classroom discussion. Are the goals of the participant reasonable? Is the portfolio sufficiently diversified? Is the portfolio too risky or too conservative? Does the participant have an adequate amount of savings? Even students with limited backgrounds in investing and personal finance may recognize that a portfolio made up entirely of the employer's stock may be imprudent.

Instructors that wish to delve more deeply into the financial planning and asset allocation process can use the information in the "Your Portfolio" columns to conduct some of the following assignments:

1. Writing an Investment Policy Statement - the information in the column can be used to construct an investment policy statement, as previously discussed in the article. In most instances, the information provided in the article will provide insufficient information to produce a detailed investment policy statement. In this case, instructors can question students about what additional information would be required to complete the investment policy statement.

2. Determining an Appropriate Asset Allocation - Using the age of the participant and any background information he or she provides, students can try to determine an appropriate asset allocation for the participant. This allocation can be compared with the participant's actual portfolio and with the recommendations provided by the financial planner.

3. Determining the Adequacy of the Investor's Savings - Students can use future value calculations to determine size of the participants nest egg at retirement and the annuity he or she will be able to receive during retirement. Online financial planning sites can also be used to determine if the participant is likely to have sufficient funds for retirement. Table 3 lists some sites with financial planning tools.

4. Analyzing the Mutual Funds in the Participant's Portfolio - Students can use the Morningstar website www.morningstar.com to analyze a number of different factors:

a. Expenses - Loads, 12b-1 fees, administrative and management fees as well as projections of costs for a $\$ 10,000$ portfolio over the next 3,5 , and 10 years are presented. Expenses of these funds can be compared to index funds and other funds in the same investment category to examine the expenses of the portfolio. One analysis that can be conducted is to see how much the actively managed fund will need to outperform the index fund by in order to cover the additional expenses.

b. Computing the Systematic Risk of the Investor's Portfolio - Using betas for the mutual funds and the stocks the participant holds, a spreadsheet can be used to compute the portfolio beta. Given the portfolio beta, the CAPM can be used to determine the required return.

c. Portfolio Performance - The Sharpe Index and Jensen's Alpha for each portfolio are presented. Jensen's Alpha is computed using the S\&P 500 Index and an index from the best fit regression. Jensen's Alpha will differ depending on the index and may be positive when using one index and negative when using the other. [Moy, 2002].

d. Tax Efficiency - The pretax return, tax-adjusted return, $\%$ rank in category and the tax cost ratio can be found in the tax analysis section.

5. Comparing Current Holdings of Mutual Funds with the Financial Planners Recommendations - In each article, a financial planner will suggest some mutual funds that the participant could substitute for his or her 
current holdings. A spreadsheet can be constructed to compare the expenses, performance, risk and tax efficiency to see if the suggested funds compare favorably to the current holdings.

Table 3

Sites with Financial Planning Tools

\begin{tabular}{ll}
\hline \multicolumn{1}{c}{ Site } & \multicolumn{1}{c}{ Web address } \\
\hline Quicken & $\underline{\text { www.quicken.com }}$ \\
Vanguard Investment Group & $\underline{\text { ww.vanguard.com }}$ \\
T.Rowe Price Investments & $\underline{\text { www.troweprice.com }}$ \\
Financial Engines & $\underline{\text { ww.financialengines.com }}$ \\
Morningstar & $\underline{\text { ww.morningstar.com }}$ \\
W.F. Sharpe's Retirement Planning Worksheet & $\underline{\text { www.stanford.edu/ wfsharpe/ws/ws_ret.htm }}$ \\
\hline
\end{tabular}

Each of the suggested assignments can be treated as shorter stand-a-lone projects or can be combined together to form a more comprehensive term project. The assignments give students an opportunity to exam the actual portfolios of the participants and gives students the chance to use tools such as online financial planning sites and Morningstar.com to further analyze the appropriateness of the investor's holdings and the financial planners recommendations.

\section{SUMMARY AND CONCLUSIONS}

Case studies can be a powerful and enjoyable way for students to apply the topics they've studied. Like other areas of finance, hands-on-experience is necessary for students to develop the necessary skills and intuition to succeed in the field of financial planning. The monthly "Your Portfolio" column appearing in USA Today provides students an opportunity to learn about, and put into practice, financial planning using financial information provided by real world individuals. Because of the range of participants in the column, instructors can illustrate the different financial goals and needs of individuals of varying ages and incomes. Instructors can use these columns to motivate discussion, as small assignments or as part of a larger term project. In all cases, students will leave the course with a better understanding of the questions and issues that must be addressed to form a sound investment plan.

\section{AUTHOR INFORMATION}

Ronald L. Moy is an associate professor of economics and finance in the Tobin College of Business at St. John's University. He received his Ph.D. in economics from Rutgers University. He is a Chartered Financial Analyst and the co-author of the Irwin Guide to Stocks, Bonds, Futures and Options.

Ralph Terregrossa is an associate professor of economics and finance in the Tobin College of Business at St. John's University. He received his Ph.D. in economics from the State University of New York at Binghamton. He is the 2008 recipient of the university's Teaching Excellence Award.

\section{REFERENCES}

1. Brinson, G. P., L.R. Hood and G.L. Beebower. "Determinants of Portfolio Performance,” Financial Analysts Journal, 42 (Winter 1986), 39-44.

2. Moy, R.L. Portfolio Performance: Illustrations from Morningstar. Journal of Education for Business, 77 (March/April 2002), 226-229.

3. Peavy, J.W. III and K.F. Sherrard. Cases in Portfolio Management. (Charlottesville, VA, 1990), AIMR.

4. Reilly, F.K. and E.A. Norton. Investments. (Fort Worth, 1999), The Dryden Press.

5. Strong, R.A. Portfolio Construction, Management, and Protection. (Mason Ohio, 2006) South-Western.

6. USA Today. various issues. 
NOTES 